\title{
Solid Wood and Veneer Study of 12-Year Old Sesenduk Clone
}

\author{
Khairul Masseat (Corresponding author), Mohd. Noor Mahat, Mohamad Omar Mohamad Khaidzir \\ Abdul Hamid Salleh, Mohd. Hafiz Musa \& Khairul Awang \\ Forest Research Institute Malaysia (FRIM) \\ 52109, Kepong, Malaysia
}

Tel: 60-3-6279-7437 E-mail: khairulm@frim.gov.my

Izran Kamal

Faculty of Forestry, Universiti Putra Malaysia, 43400 Serdang, Selangor, Malaysia

E-mail: izran_kamal@yahoo.com

The research is financed by Forest Research Institute Malaysia. GPP-TM-1208-01/41310402001

\begin{abstract}
Physical and mechanical properties of solid sesenduk clone were studied using physical tests such shrinkage and specific gravity and mechanical tests such as modulus of rupture (MOR), modulus of elasticity (MOE), compression strength, hardness and shear strength. The solid woods were tested under two different conditions (green and air-dried). The grading of solid sesenduk clone was also conducted by using Acacia mangium as material for comparison. The sesenduk clone was also transformed to veneer and compared with Acacia mangium. From the experiments, it can be concluded that sesenduk clone showed good quality and properties which make it becomes suitable as a supplement raw material in future.
\end{abstract}

Keywords: Sesenduk clone, Matured sesenduk, Physical, Mechanical, Air-dried and green

\section{Introduction}

Rubberwood is almost exclusively as a raw material for the production of particleboard and medium density fibreboard (MDF) in Malaysia. This wood species is also responsible for the establishment and growth of the Malaysian wood-based in particular MDF, particleboard, wood lamination and furniture. However, due to the demand of rubberwood that keeps increasing, the price is also increasing since the last decade (Paridah et al., 2009). The increase of the price surely has caused a burden to the wood-based product manufacturers. This situation has urged them to find alternative materials that can help them continuously producing wood-based products with reasonable cost. Sesenduk has been discovered to be a suitable tree species for such purpose. Sesenduk is one of the fast-growing species and possesses good mechanical and physical properties and astonishing wood colour. Other than that, according to MTC (Malaysian Timber Certification), sesenduk is extremely easy to be treated with chemicals (fire retardants or wood preservers) and it has excellent working properties nailing (MTC, 2008). Due to that, sesenduk is suitable for fabrication of wood furniture or wood-based products such particleboard, plywood and veneer. This study is to promote the 12 years old sesenduk clone (FRIMsrp001). This species has been selected as one of the potential species for plantation establishment, because of the demand of the species and the rate of the growth, even though its seed germination was found as low as $10 \%$ due to the attack of the seed borer, Dichocrocis punctiferalis (Darus et al., 1991). The objectives of the project are: 1) To determine the timber recovery and timber grade of 12 years old sesenduk clone, 2) To fabricate solid and veneer products of 12 years old sesenduk clone 3) To determine the veneer recovery and veneer quality, 4) To determine the physical and mechanical properties of solid wood and flat board (plywood board).

\section{Materials and Method}

\subsection{Materials}

Raw material used for the study was 12 years old sesenduk clone which was obtained from the Kepong Botanical Garden (KBG), FRIM plot. This project was divided into two different studies i.e. solid and veneer study. Samples for solid study (physical and mechanical properties) were cut in accordance with American Standard Testing Method (ASTM D5536-97). 


\subsection{Solid Study and Veneer Study}

For this study, investigations done were on recovery, physical and mechanical properties, timber grading, product development and furniture testing. The properties were tested under green and air-dried conditions in accordance with BS 373:1957 (method of testing small clear specimen for timber). Tests done on the samples were specific gravity, density, shrinkage, moisture content (MC), modulus of rupture (MOR), modulus of elasticity (MOE), shear strength, compression and hardness. The timber was graded by MTIB's grader and by referring to Malaysian Grading Rules (MGR). As for veneer study, it comprises recovery rate study, veneer quality, physical and mechanical properties, product development and furniture testing.

\subsection{Data analysis}

The samples were analyzed using ANOVA. The analysis was to determine the effects of different drying conditions to the physical and mechanical properties. The mean values for each parameter under each species were compared to determine significance effects caused by the drying surroundings at $\mathrm{p} \geq 0.05$.

\section{Results and Discussions}

\subsection{Solid Study}

The physical and mechanical properties of the 12 years old sesenduk clone which were tested under two different environments (green and air-dried) were compared with 40-year old matured sesenduk and rubberwood. The results are exhibited in Table 1.

\subsubsection{Mechanical Properties}

The MOR, MOE, hardness, shear strength and compression were better when the samples were air-dried prior to the tests. Moisture content was observed as one of the factor that influenced the results. The air-dried matured sesenduk presented the lowest moisture content (n.a) and this is why it showed the best MOR and MOE values. The air-dried mature sesenduk was able to achieve MOR and MOE values as high as $80 \mathrm{~N} / \mathrm{mm}^{2}$ and 10000 $\mathrm{N} / \mathrm{mm}^{2}$, which was almost $50 \%$ higher than sesenduk clone and rubberwood. The other three tests (hardness, shear strength and compression) were conquered by rubberwood, even though, for these tests, the air-dried rubberwood was having similar moisture content with the air-dried 12 year old sesenduk clone. It recorded 4.3 $\mathrm{kN}$ for hardness, $11.0 \mathrm{~N} / \mathrm{mm}^{2}$ for shear strength and $32.3 \mathrm{~N} / \mathrm{mm}^{2}$ for compression. As for the green samples, the comparisons were only made between green matured sesenduk and green sesenduk clone. In green condition, still, the matured sesenduk exhibited better mechanical performance in comparison with sesenduk clone (Table $1)$.

\subsubsection{Physical Properties}

Shrinkage was evaluated based on the air-dried samples. No value was found for rubberwood. By comparing the shrinkage values, between the green mature sesenduk and the green 12-year old sesenduk clone, it was found that the mature sesenduk was more dimensional stable than the sesenduk clone. The larger percent of shrinkage indicates less dimensional stability. For tangential shrinkage, the values for the matured sesenduk and sesenduk clone were $1.45 \%$ and $1.82 \%$, where as for radial shrinkage, the values were $2.22 \%$ and $2.50 \%$. This is normal, because naturally, moisture content of a juvenile wood is gradually decreasing as it grows. Hence, it becomes more dimensional stable as the shrinkage value is also decreasing as found by Kretschman and Bendtsen (1993). Other than that, it might be caused by the density difference. According to Guler et al.,(2007) density is an important factor which is affecting shrinkage and swelling of a wood. The mature sesenduk has greater density compared to the sesenduk clone and it was able to hold more moisture, which this might explain why it released moisture slower than the sesenduk clone. The overall inferior physical and mechanical properties of the sesenduk clone can be fully understood by evaluating them through the findings of Kretschman and Bendtsen (1993). Kretschman and Bendtsen (1993) explain that a juvenile wood is much lower strength, lower specific gravity, thinner cell walls, lower cellulose content, lower percentage of latewood, higher longitudinal shrinkage, more compression wood, greater fibril angle and higher lignin content compared to a mature wood. These parameters are believe to affect the properties of the sesenduk clone. As for the recovery rate, the comparison was made between sesenduk clone and Acacia mangium. The intention of choosing Acacia mangium as a threshold for comparison was because Acacia mangium is one of the well-known fast-growing species, which is already attain great acceptance among wood-based manufacturers. The recovery rate of sesenduk clone was better than that of Acacia mangium. The yield recovery rate for sesenduk clone was 52\% and Acacia mangium was $41 \%$. Sesenduk clone once again overshadowed Acacia mangium for timber grading. There were 7 characteristics assessed for the grading: 1) prime, 2) select, 3) standard, 4) service-able, 5) sound, 6) utility and 7) reject. The values of prime, select, standard, service-able, sound and utility should be high in order to achieve good grading. The 
lower the reject value presents better grading. The values for sesenduk clone for those characteristics were: 2.5 , 14.7, 73, n.a, 6.1 and 3.6\% and slight lower values for Acacia mangium: 12.9, 7.9, 36.3, 0.5, 4.5 and 37.8\%. Roughly, sesenduk clone was eligible to become a substitute for Acacia mangium as an input for the wood-based industry. Sesenduk clone comes with acceptable physical and mechanical properties and short period of growth to achieve harvestable maturity.

\subsection{Veneer Study (recovery rate and shrinkage)}

For veneer study, the sesenduk clone veneer was compared with Acacia mangium veneer. The sesenduk clone veneer properties were greater than that of Acacia mangium. The properties were evaluated through recovery rate and shrinkage (thickness, parallel and perpendicular). Higher recovery and lower shrinkage values indicate good properties. The recovery rate for sesenduk clone and Acacia mangium were 76 and 46\%, whereas the shrinkage rates were 3.9\% (thickness), 3.75\% (parallel) and $0.25 \%$ (perpendicular) for sesenduk and 2.8\% (thickness), $4.22 \%$ (parallel) and 2.75\% (perpendicular) for Acacia mangium. The sesenduk clone veneer also was found resistance to defects such as pin holes, worm tracks and open slits. This probably due to the high lignin content that sesenduk clone has which it acts as defence against the wood borers. The physical and mechanical properties of the flat board from sesenduk were decreasing as the resin loading and pressing time was increased. The heat of the pressing was believed to affect the strength of the wood fibres and caused decrease to the strength of the veneer. However this is subject to the pressing duration. The pressing duration is frequently adjusted to be longer as resin loading is increased. The intention of this act is to eliminate moisture available in the resin as well as in the wood to help the resin cure faster, thus create bonding between veneer and resin. The effects of resin loading to pressing time are studied in details by Izran (2009) and Izran et al., (2010b), even though the final product of his research was particleboard. The pressing duration is also not only affected by resin loading, but it is also may be affected by the chemical composition of the material. This had been confirmed by Izran et al., (2010a) and Zaidon et al., (2004).

\section{Conclusions}

This study concluded that the rubberwood is still incomparable by the mature sesenduk solid wood and sesenduk clone solid wood, in terms of physical and mechanical properties. However the matured sesenduk was better than the sesenduk clone. Sesenduk clone also having a better grading compared to Acacia mangium which has made it compatible to be a successor or an alternative to Acacia mangium. With all the advantages it has, the sesenduk clone should be further promoted to provide wider selection of raw material for the wood-based product manufacturers in continuously producing wood-based products that have received non-stop demand. It may prevents the manufacturers from just concentrating to a species which, without warning may cause distinction to the species.

\section{Acknowledgements}

A special thank to FRIM for securing grant for this project and to members of FRIM for the supervisions and helps for this research work.

\section{References}

BS 373: (1957). Methods of testing small clear specimens of timber. Standard status reconfirmed on November 2008.

Darus, A, Hashim,M.N., Abd. Rasip, A.G. and LOG, E.H. (1991). Khaya ivorensis and Endospermum malaccense as potential species for future reforestration programmes, In Proceedings of a Conference on Malaysia Forestry and Forest Products Research, 3-4th October 1990. Forest Research Institute Malaysia

Guler, C., Copur, Y., Akgul, M. and Buyuksari, U. (2007). Some chemical, physical and mechanical properties of juvenile wood from black pine (Pinus nigra Arnold) Plantations, Journal of Applied Sciences 7(5):755-758

Izran, K., Koh. M.P., Tan, Y.E and Faezah, M. (2010a). Buffering Capacity of Fast-Growing Species and Curing Time of UF Resin Modified with Zinc Borate and Monoammonium Phosphate, Unpublished report of FRIM-ITTO Project 2009.

Izran, K., Koh, M.P., Tan, Y.E., Saimin, B., Nordin, P., Rosly, M.J. and Naziffuad,N. (2010b). Physical and mechanical assessments of fire retardant-treated Shorea macrophylla and Acacia mangium Particleboards, Unpublished report of FRIM-ITTO Project 2009.

Kretschmann, D.E. and Bendtsen B. A. (1993). Ultimate tensile stress and modulus of elasticity of fast-grown plantation loblolly pine lumber. Journal of Wood Fiber Science. 24(2): 189-203.

Lee YH. et al. (1979). The strength properties of some Malaysian timbers. Forestry Department Peninsular 
Malaysia, 56.

MTC. (2008). Specifications of Popular Malaysian Timber: General Properties, Technical Report, Available online: http://www.mtc.com.my/industry/index.php?option=com_content $\&$ view=article \&id=74\&Itemid=63

Paridah, M.T., Nor Hafizah, A., Zaidon, A. Azmi, I., Mohd Nor, M.Y and Nor Yuziah, M.Y. (2009). Bonding properties and performance of multi-layered kenaf board, Journal of Tropical Science 21(2):113-122

Zaidon,A., Paridah,M.T., Sari,C.K.M., Razak,W., and Yuziah M.Y.N. (2004). Bonding characteristics of Gigantochloa scortechinii. Journal of Bamboo and Rattan 3(1): 1-9

Table 1. Physical and mechanical properties of the solid sesenduk clone, mature sesenduk and rubberwood

\begin{tabular}{|c|c|c|c|c|c|}
\hline \multirow{2}{*}{ Properties } & \multicolumn{2}{|c|}{ 12-year old sesenduk clone } & \multicolumn{2}{|c|}{ Mature sesenduk } & \multirow{2}{*}{$\frac{\text { Rubberwood }}{\text { Air-dried (1) }}$} \\
\hline & Green & Air-Dried & Green (1) & Air-Dried (2) & \\
\hline MC (\%) & 103 & 17 & 76 & n.a & 17 \\
\hline Density $\left(\mathrm{Kg} / \mathrm{m}^{3}\right)$ & 311 & 323 & 400 & 500 & 640 \\
\hline $\operatorname{MOR}\left(\mathrm{N} / \mathrm{mm}^{2}\right)$ & 38.13 & 48.21 & 39 & 80.57 & 66 \\
\hline $\operatorname{MOE}\left(\mathrm{N} / \mathrm{mm}^{2}\right)$ & 4472 & 5618 & 8500 & 10678 & 9240 \\
\hline Hardness (KN) & 1.2 & 1.3 & 1.6 & n.a & 4.3 \\
\hline Shear $\left(\mathrm{N} / \mathrm{mm}^{2}\right)$ & 4.7 & 6.1 & 5.4 & 9.7 & 11.0 \\
\hline Compression(N/mm²) & 18.4 & 24.2 & 20.8 & n.a & 32.3 \\
\hline Specific gravity & 0.31 & 0.32 & 0.33 & n.a & 0.55 \\
\hline $\begin{array}{c}\text { Tangential shrinkage }(\%)- \\
\text { Air Dried }\end{array}$ & \multicolumn{2}{|c|}{1.82} & n.a & 1.45 & n.a \\
\hline $\begin{array}{c}\text { Radial Shrinkage }(\%)- \\
\text { Air Dried }\end{array}$ & \multicolumn{2}{|c|}{2.50} & n.a & 2.22 & n.a \\
\hline
\end{tabular}

Samples of 12 for each portion (bottom, middle and top)

Note:

(1) The Strength Properties of Some Malaysian Timbers, 1979.

(2) Poster Presented at IUFRO, Taiwan by Hamdan et. al,.2007. 